\title{
What Drives Long Term Real Interest Rates in Brazil?
}

\author{
Adonias Evaristo da Costa Filho ${ }^{\dagger}$ \\ ASP student - Kiel Institute for the World Economy
}

\section{ABSTRACT}

This paper investigates the drivers of long term real interest rates in Brazil. It is shown that long term yield on inflation linked bonds are driven by yields on 10 year interest rates of United States (US) government bonds and 10 year risk premium, as measured by the Credit Default Swap (CDS). Long term interest rates in Brazil were on a downward trend, following US real rates and stable risk premium, until the taper tantrum in the first half of 2013. From then onwards, real interest rates rose due to the increase in US real rates in anticipation of the beginning of monetary policy normalization and, more recently, due to a sharp increase in Brazilian risk premium. Policy interest rates do not significantly affect long term real interest rates.

Keywords: Interest rates, Risk premium, Monetary policy, Tapering.

\section{INTRODUCTION}

Since mid-2000's there is availability of long term interest rate measures for Brazil, expressed in long term inflation linked bonds issued by the Brazilian National Treasury. The purpose of this paper is to try to find the variables that explain the movements in long term real yields, contributing to the literature on the drivers of real rates in Brazil.

Brazil's persistent high interest rate levels have always puzzled many economists. Many explanations have been developed for this feature in Brazilian economy. Jaeger (2012) summarizes the main hypothesis: i) fiscal weakness, ii) low domestic savings rate, iii) institutional shortcomings, iv) past history of high inflation and inflation volatility and v) credit market segmentation.

Arida, Bacha and Lara-Resende (2004) blamed jurisdictional uncertainty and the lack of convertibility of the Real for the persistently high levels of real interest rates in Brazil, but Gonçalves, Holland and Spacov (2007) failed to find empirical support to this theory, particularly when compared to standard monetary and fiscal factors.

Neto and Portugal (2005) estimates the natural interest rate for Brazil in the early years of the inflation targeting regime, overall finding that the monetary policy stance for that period could be characterized by neutral, in the sense that the real rates obtained from a dynamic Taylor rule and ex-ante rates were close to a series estimated for the natural rate.
Corresponding author:

${ }^{\dagger}$ ASP student - Kiel Institute for the

World Economy.

E-mail: adoniasevaristo@hotmail.com

Received: 02/22/2016.

Revised: 06/29/2016.

Accepted: 09/15/2016.

Published Online: 07/01/2017.

DOI: http://dx.doi.org/10.15728/bbr.2017.14.6.5 
Ribeiro and Teles (2010) extended the approach in Neto and Portugal (2005) to the period 2001-2010, finding a declining path for the natural rate since 2006. Using the interest rate gap concept, they argued that monetary policy was tight from 1999 to 2005, while from 2005 to 2010 the monetary policy stance was probably neutral.

Bacha (2010) explains the difference in real interest rates in Brazil and the world from 1995 to 2009, using lags of the interest rate and lags of level of the net public debt. He argues that the level of public debt, issues related to its sustainability and the inflationary past of the Brazilian economy are the main determinants of the high level of real interest rates in Brazil.

Goldfajn and Bicalho (2011) distinguish short and long term equilibrium real interest rates in Brazil. Models estimated from 1999 to 2008 indicate that outstanding credit as a share of GDP, the level of debt and risk premium, measured by the EMBI, are significant in explaining the ex-ante real interest rate, taking this as a measure of long term real rate. The short term is derived from estimates of a IS curve that include gaps of the output, international output, fiscal expenditures, earmarked credit and real exchange rate. They also emphasize the uncertainty surrounding the estimates of the equilibrium real rate for the Brazilian economy.

Segura-Ubiergo (2012) uses data from 15 emerging market countries over the period 1980-2009 to investigate the determinants of short-term real rates. The author estimates a panel vector error correction model (VEC) with many macroeconomic controls, finding that reduced inflation volatility, introduction of the inflation targeting regime, international financial conditions and domestic savings are all significant associated with short term real rates in emerging markets. While real rates drops with reduced inflation volatility and the introduction of the inflation targeting regime, tighter financial conditions and lower domestic savings lead to an increase in real rates. The study stress the importance of higher savings in order to decrease real rates in Brazil.

Muinhos and Nakane (2006) employed several different methodologies (filtered rates, IS curves, marginal productivity of capital estimates, panel regression) to analyze Brazilian real interest rates in comparison to a large number of countries. They also raise doubts about the links between high interest rates and debt levels, finding that interest rates Granger cause debt levels in Brazil. Finally, they raise the possibility that inflation uncertainty may explain high real rates levels, based on the differences between ex-ante and ex-post real rates in Brazil.

Using a variety of methods, Perrelli and Roache (2014) documents a large fall in the neutral rate in Brazil, due to domestic and external factors, although at the time the paper was written real rates in Brazil remained high in comparison to country peers.

The contribution of this paper is to assess the drivers of long term real interest rates, which have in fact been negotiated in the market for more than 10 years. All the aforementioned studies used the policy rate or a short rate (usually swap rates) as a measure of real rate, and there can be significant differences in the behavior of these series. One potential shortcoming of using short term real rates is that reductions in these variables driven by cuts in nominal policy interest rates might not be sustained over time. On the other hand, increases in the nominal short term real rates might reflect transitory movements that should not reflect significant changes in the neutral real rate. One methodology of Perrelli and Roache (2014) represents an attempt in this direction. They back out the neutral interest rate by adding the difference between the current term premium and its average over the period 2006-2013 to the trend real short term interest rate. Bonfim (2001) tried to assess US equilibrium rate through inflation linked bonds, and is the closest attempt to the one pursued here.

Figure 1 shows the evolution of short term real rate - Selic rate deflated by the expected inflation in the next 12 months from the Focus survey and the long term real yield from the NTN-B. Real policy rates were above long term real yields until March of 2009. From this 
BBR

14,6

626

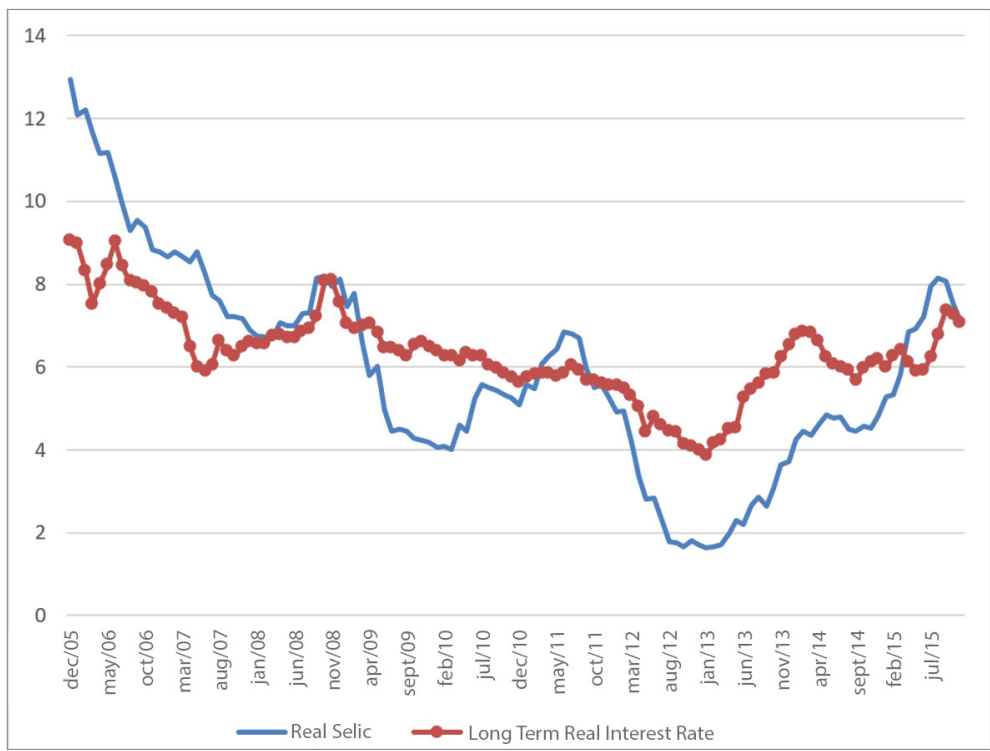

Figure 1. Real policy and long term real interest rates.

Source: Author's elaboration.

month onwards, policy real rates remained below long term real yields, with the exception of few months during 2011 and 2015. One feature of both series is that the real policy rate is much more volatile than long term yields. For the former, the standard deviation from December 2005 to November 2015 is $2.52 \%$ with an average of $5.94 \%$, resulting in a coefficient of variation of 42.4 . For the latter, the standard deviation is $1.07 \%$ and sample average of 6.32 , implying a coefficient of variation of 16.93 . Thus, real long term yields were more stable during the period under analysis.

About the differences in behavior between short and long rates, Perrelli and Roache (2014, p.21) comment that "These estimates provide very strong evidence that the shortrun and long-run equilibrium real rates can diverge substantially, reflecting both domestic and external factors and the stance of monetary policy." Along the same lines, arguing in favor of using inflation linked bonds to extract information about the equilibrium real rate, Bonfim (2001) points out that “..., long-dated TIIS yields should reflect investors' views of where real short rates will be after temporary macroeconomic imbalances have worked themselves through."

This research is not an attempt to test the competing theories for the level of interest rates in Brazil, but rather to try to model long term real rates and obtain information about the neutral real rates from them.

\section{DATA}

As a measure of long term real yields in Brazil, I use the yields on Nota do Tesouro Nacional (NTN-B), available on Bloomberg. From December of 2005 to February 2010, the long term real yield is represented by the NTN-B maturing in May, 2045, which was the longest bond issued during this period. From February 2010 onwards, the long term real yield used is the NTN-B maturing in August, 2050. This follows the use of "on-therun" bonds in Bonfim (2001), which tend to be more liquid. The series used are mid yield obtained on Bloomberg platform, and are monthly averages.

I checked the following variables as potential drivers of long term yields in Brazil: i) 10 and 30-year yields on inflation linked bonds issued by the American Treasury - Treasury Inflation Protected Securities (TIPS), also obtained from Bloomberg, ii) 10 and 30 year levels of Credit Defaut Swaps (CDS) on Brazil's credit, collected on Bloomberg as well 
iii) fiscal deficit, as measured by the Consolidated Public Sector Primary Deficit or Surplus as a percentage of GDP, iv) Selic target rate deflated by the expected inflation (IPCA) for the next 12 months from the Focus survey as a measure of short term real rate, v) ratios of the total issuance of inflation linked bonds relative to total issuance, as technical factor, representing the supply pressure, and also the total issuance of bonds relative to the redemptions, also trying to capture technical factors.

As in Goldfajn and Bicalho (2011) and Perrelli and Roache (2014), I also examined whether the lags of credit at market rates to GDP, earmarked credit and total credit to GDP ratio were significant in the equations, but none of them were. The same happened to the lags of gross debt relative to GDP, for which I also failed to find statistical significance. A possibility is that these variables influence the real interest rate through the risk premium.

Table 1 shows the results from unit root tests performed on the variables used in the paper. I conducted both Philips-Perron and DF-GLS tests. It is also shown the sources of each variable.

\section{RESULTS}

Results are presented on table 2, which shows the outcomes of four different specifications. Since credit and debt variables were not statistically significant, the specification in the first column is the preferred one.

Basically, long term real rates in Brazil are mainly driven by 10 year real rates in United States and 10 year risk premium, measured by the CDS spreads. Short term real rates, the Selic real rate deflated by expected inflation, were not significant. An attempt was made to assess whether measures of slopes between the 10 and 30 year American real rates and risk premium drive long term real rates in Brazil, but none of them were.

The model does a fairly good job in explaining the evolution of long real rates in Brazil, considering its large explanatory power (96\%). The Ramsey RESET test does not indicate omitted variables, yielding a p-value of 0.60 , so that it fails to reject the hypothesis of no omitted variables.

Table 3 presents the Q-Jung Box tests on the residuals and squared residuals of the first specification, in order to assess autocorrelation and heteroskedasticity. While there is no indication of autocorrelation, there is indication of heteroskedasticity, which could not be solved by ARCH and GARCH effects, as indicated on Table 4, where is shown that they were not significant, up to a second lag. In order to try to solve the heteroskedasticity problem, both a $\operatorname{GARCH}(1,1)$ and a $\operatorname{GARCH}(2,2)$ were estimated. These models were estimated assuming that the errors follow a Generalized Error Distribution (GED), which emcompasses the normal, uniform and Laplace distributions as particular cases.

Finally, skewness and kurtosis tests for normality indicated that residuals of the model have a normal distribution, failing to reject the hypothesis of normality with an associated p-value of 0.18 .

\section{ASSESSING COINTEGRATION}

Results from the previous section indicate that long term real rates in Brazil are mainly driven by US long term real rates and the risk premium, measured by the CDS spreads. Since the residuals from our preferred specification, shown on Figure 2, are stationary, this is equivalent to a real interest parity in long term real rates in Brazil. One could eventually question if domestic real rates, US real rates and CDS spreads are cointegrated, i.e., whether there is a long term relationship between these variables and they contain a common stochastic trend. Since long term real rates in Brazil are borderline stationary, as pointed by the Philips Perron unit root test presented on table 1, in this section I investigate this issue, assuming that the variables are nonstationary. 
Table 1. Variables, Sources and Unit Root Tests

\begin{tabular}{|c|c|c|c|c|}
\hline Number & Variables & Source & Philips-Perron (p-value) & DF-GLS Statistic \\
\hline 1 & Brazil Long Term Real Interest Rate & $\begin{array}{c}\text { Bloomberg (Tickers BNTNB } 6 \\
\text { 05/15/2045 Govt and BNTNB } 6 \\
\text { 08/15/2050 Govt }\end{array}$ & 0.0938 & -1367 \\
\hline 2 & $\begin{array}{c}\text { Yield on US } 10 \text {-year Inflation } \\
\text { Linked Bond }\end{array}$ & Bloomberg (Ticker GTII10 Govt) & 0.5579 & -2036 \\
\hline 3 & $\begin{array}{c}\text { Yield on US 30-year Inflation } \\
\text { Linked Bond }\end{array}$ & Bloomberg (Ticker GTII30 Govt) & 0.5223 & -2285 \\
\hline 4 & Difference between 3 and 1 & - & 0.4035 & -1402 \\
\hline 5 & 10 year Credit Default Swap & $\begin{array}{c}\text { Bloomberg (Ticker BRAZIL CDS } \\
\text { USD SR 10Y D14) }\end{array}$ & 0.3879 & -1863 \\
\hline 6 & 30 year Credit Default Swap & $\begin{array}{c}\text { Bloomberg (Ticker BRAZIL CDS } \\
\text { USD SR 30Y D14) }\end{array}$ & 0.6779 & -2283 \\
\hline 7 & Difference between 6 and 5 & & 0.0751 & $-3959^{* * *}$ \\
\hline 8 & Consolidated Primary Fiscal Deficit & Central Bank of Brazil - Series 5364 & 0.0000 & -0.992 \\
\hline 9 & Gross Public Debt & $\begin{array}{c}\text { Central Bank of Brazil - Series } \\
13762\end{array}$ & 0.0413 & $-4770^{* * *}$ \\
\hline 10 & Credit At Market Rates & $\begin{array}{c}\text { Central Bank of Brazil - Series } \\
20625\end{array}$ & 0.0837 & -1156 \\
\hline 11 & Earmarked Credit & $\begin{array}{c}\text { Central Bank of Brazil - Series } \\
20628\end{array}$ & 0.5072 & -2244 \\
\hline 12 & Total Credit & $\begin{array}{c}\text { Central Bank of Brazil - Series } \\
20622\end{array}$ & 0.1500 & -1447 \\
\hline 13 & $\begin{array}{l}\text { Selic Target Rate Deflated by } \\
\text { Expected Inflation (IPCA) for the } \\
\text { next } 12 \text { months }\end{array}$ & $\begin{array}{l}\text { Central Bank of Brazil - Series } \\
4189 \text { and } 12 \text { month ahead expected } \\
\text { IPCA inflation (monthly average) }\end{array}$ & 0.0531 & -2003 \\
\hline
\end{tabular}

\section{8}

***, ${ }^{* *},{ }^{*}$ : Statistically significant at the 1,5 and $10 \%$ level, respectively.

Since the residuals showed on figure 2 are stationary, and the estimated equation has theoretical grounds (real interest rate parity), the possibility of spurious regression is ruled out, but we could be potentially missing a cointegration relationship between the variables. For this reason, and in order to complement the analysis, I regress the Brazilian long term real rate on the US long term real rate and 10 year CDS spreads using least squares, and then test the stationarity of the residuals. This is equivalent to an Engle-Granger cointegration test. In a second step, I examine cointegration involving long term real rate in Brazil, US long term real rate and 10 year CDS spreads based on the Johansen methodology.

Based on the Engle-Granger method I found a cointegration relationship between these variables. Table 5 presents the results of a regression of Brazil long term real rate against US long term real rate and 10 year CDS spreads and a constant. All coeficients and statistically significant at the $1 \%$ level. The constant of the regression is $4.38 \%$, which can be interpreted as the neutral or natural long term real rate in Brazil over the sample period, absent any influence from foreign real rates and the domestic risk premium. The Philips Perron test rejects the null of a unit root at the residuals, yielding a p-value of 0.0041 . On the other hand, DF-GLS indicates a unit root in the residuals, failing the reject the null on the lags selected by the information criteria. Although the Engle-Granger methodology pointed to a cointegration relationship between the variables, the Johansen methodology failed to indicate the presence of a cointegrated vector among the variables*. Nonetheless, considering that the results might be influenced by the relatively short sample, I estimated a Vector Error Correction Model (VECM), with the results showing one cointegration relationship, and the results are presented below, with All coefficients are being statiscally significant at the $1 \%$ level (Table 6):

\footnotetext{
* The test used a constant and 2 lags, as indicated by the information criteria
} 
Table 2. Regressions results

\begin{tabular}{|c|c|c|c|c|}
\hline \multirow{2}{*}{ Variables } & (1) & (2) & (3) & (4) \\
\hline & Real Rate & Real Rate & Real Rate & Real Rate \\
\hline \multirow{2}{*}{ Real Rate(-1) } & $1.081^{* * *}$ & $1.089^{* * *}$ & $1.085^{* * *}$ & $1.048^{* * *}$ \\
\hline & $(0.114)$ & $(0.113)$ & $(0.115)$ & $(0.0981)$ \\
\hline \multirow{2}{*}{ Real Rate(-2) } & $-0.251^{* *}$ & $-0.250^{* *}$ & $-0.257^{* *}$ & $-0.246^{* * *}$ \\
\hline & $(0.106)$ & $(0.105)$ & $(0.104)$ & $(0.0898)$ \\
\hline \multirow{2}{*}{ US Real Rate $10 \mathrm{y}$} & $0.140^{* * *}$ & $0.245^{* *}$ & $0.243^{* *}$ & $0.212^{* * *}$ \\
\hline & $(0.0393)$ & $(0.118)$ & $(0.116)$ & $(0.0552)$ \\
\hline \multirow{2}{*}{ CDS10 } & $0.498^{* * *}$ & $0.479^{* * *}$ & $0.471^{* * *}$ & $0.426^{* * *}$ \\
\hline & $(0.0736)$ & $(0.0784)$ & $(0.0816)$ & $(0.0623)$ \\
\hline \multirow{2}{*}{$\operatorname{CDS} 10(-1)$} & $-0.427^{* * *}$ & $-0.413^{* * *}$ & $-0.404^{* * *}$ & $-0.377^{* * *}$ \\
\hline & $(0.0820)$ & $(0.0844)$ & $(0.0866)$ & $(0.0723)$ \\
\hline \multirow{2}{*}{ Earmarked Credit } & & & & -0.00660 \\
\hline & & & & $(0.0190)$ \\
\hline \multirow{2}{*}{ Credit/GDP } & & & & 0.0184 \\
\hline & & & & $(0.0167)$ \\
\hline \multirow{2}{*}{ Debt/GDP } & & & & -0.0317 \\
\hline & & & & $(0.0297)$ \\
\hline \multirow{2}{*}{ Debt/GDP(-1) } & & & & 0.0315 \\
\hline & & & & $(0.0297)$ \\
\hline \multirow{2}{*}{ US Real Rate $10 y(-1)$} & & -0.116 & -0.117 & \\
\hline & & $(0.124)$ & $(0.124)$ & \\
\hline \multirow{2}{*}{ Real Selic } & & & 0.00684 & \\
\hline & & & $(0.0165)$ & \\
\hline \multirow{2}{*}{ Constant } & $0.767^{* * *}$ & $0.730^{* * *}$ & $0.763^{* * *}$ & 0.223 \\
\hline & $(0.197)$ & $(0.208)$ & $(0.215)$ & $(0.641)$ \\
\hline Observations & 118 & 118 & 118 & 105 \\
\hline R2 & 0.963 & 0.964 & 0.964 & 0.959 \\
\hline
\end{tabular}

Robust standard errors in parentheses. ${ }^{* * *} \mathrm{p}<0.01,{ }^{* *} \mathrm{p}<0.05,{ }^{*} \mathrm{p}<0.1$.

Table 3. Q-Ljung Box tests on residuals and squared residuals

\begin{tabular}{lcccc}
\hline Lags & \multicolumn{2}{c}{ Residuals } & \multicolumn{2}{c}{ Squared Residuals } \\
\hline 1 & $\mathrm{Q}$ & Prob>Q & $\mathrm{Q}$ & 0.0001 \\
2 & .11746 & 0.7318 & 14.587 & 0.0002 \\
3 & .3288 & 0.8484 & 16.629 & 0.0007 \\
4 & .59496 & 0.8976 & 17.105 & 0.0018 \\
5 & 10.326 & 0.9048 & 17.116 & 0.0043 \\
6 & 15.255 & 0.9101 & 17.134 & 0.0064 \\
7 & 22.923 & 0.8909 & 17.935 & 0.0094 \\
8 & 3.047 & 0.8806 & 18.63 & 0.0162 \\
9 & 31.866 & 0.9221 & 18.757 & 0.0265 \\
10 & 31.868 & 0.9564 & 18.851 & 0.0393 \\
\hline
\end{tabular}

Overall the results are close to those presented on table 5. By the estimated cointegration relationship, the natural or long term real rate derived from inflation linked bonds in Brazil is $4.59 \%$, absent any influences from CDS spreads and US long term real rate. This result is slightly above the one using the Engle-Granger methodology (4.38\%). 
BBR

14,6

630
Table 4. Testing for ARCH and GARCH effects

(1)

(2)

(4)

(5)

$\operatorname{GARCH}(2,2)$

\begin{tabular}{|c|c|c|c|c|}
\hline VARIABLES & Real Rate & $\operatorname{GARCH}(1,1)$ & Real Rate & $\operatorname{GARCH}(2,2)$ \\
\hline \multirow{2}{*}{ Real Rate $(-1)$} & $1.083^{* * *}$ & & $1.096^{* * *}$ & \\
\hline & $(0.0766)$ & & $(0.0759)$ & \\
\hline \multirow{2}{*}{ Real Rate (-2) } & $-0.248^{* * *}$ & & $-0.265^{* * *}$ & \\
\hline & $(0.0618)$ & & $(0.0603)$ & \\
\hline \multirow{2}{*}{$\begin{array}{l}\text { US Real Rate } \\
10 \mathrm{Y}\end{array}$} & $0.197^{* * *}$ & & $0.223^{* * *}$ & \\
\hline & $(0.0754)$ & & $(0.0759)$ & \\
\hline \multirow{2}{*}{$\begin{array}{l}\text { US Real Rate } \\
10 \mathrm{y}(-1)\end{array}$} & -0.0610 & & -0.0816 & \\
\hline & $(0.0748)$ & & $(0.0764)$ & \\
\hline \multirow{2}{*}{ CDS $10 \mathrm{Y}$} & $0.408^{* * *}$ & & $0.403^{* * *}$ & \\
\hline & $(0.0569)$ & & $(0.0567)$ & \\
\hline \multirow{2}{*}{ CDS $10 Y(-1)$} & $-0.341^{* * *}$ & & $-0.333^{* * *}$ & \\
\hline & $(0.0625)$ & & $(0.0658)$ & \\
\hline \multirow{2}{*}{$\mathrm{ARCH}(-1)$} & & 0.338 & & 0.367 \\
\hline & & $(0.255)$ & & $(0.245)$ \\
\hline \multirow{2}{*}{ GARCH (-1) } & & 0.00865 & & -0.407 \\
\hline & & $(0.537)$ & & $(0.834)$ \\
\hline \multirow{2}{*}{ ARCH (-2) } & & & & 0.199 \\
\hline & & & & $(0.395)$ \\
\hline \multirow{2}{*}{ GARCH (-2) } & & & & -0.253 \\
\hline & & & & $(0.292)$ \\
\hline \multirow{2}{*}{ Constant } & $0.758^{* * *}$ & 0.0245 & $0.774^{* * *}$ & $0.0415^{*}$ \\
\hline & $(0.168)$ & $(0.0158)$ & $(0.165)$ & $(0.0238)$ \\
\hline Observations & 118 & 118 & 118 & 118 \\
\hline
\end{tabular}

Observations

118

118

118

118

*** $\mathrm{p}<0.01,{ }^{* *} \mathrm{p}<0.05,{ }^{*} \mathrm{p}<0.1$.

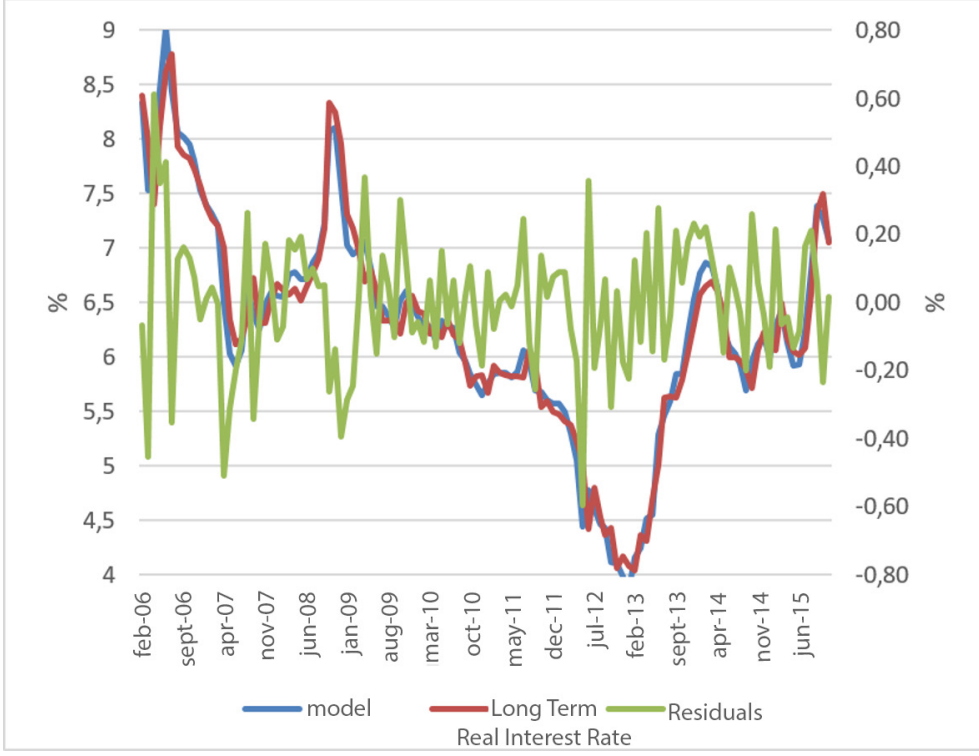

Figure 2. Fitted Values and Residuals

Source: Author's elaboration 
Table 5. Engle-Granger procedure

\begin{tabular}{lc}
\hline VARIABLES & (1) Real Rate \\
\hline US Real Rate 10Y & $0.876^{* * *}$ \\
& $(0.0452)$ \\
CDS 10Y & $0.512^{* * *}$ \\
& $(0.0568)$ \\
Constant & $4.385^{* * *}$ \\
& $(0.133)$ \\
Observations & 120 \\
R-squared & 0.798 \\
\hline Standard errors in parentheses & \\
*** $^{*}<0.01,{ }^{* *} \mathrm{p}<0.05,{ }^{*} \mathrm{p}<0.1$. & \\
\end{tabular}

BBR

14,6

631

Table 6. Cointegration Equation

\begin{tabular}{lcccc}
\hline Variables & Real Rate & Standard Error & Z Statistics & P>|z| \\
\hline US Real Rate 10Y & 0.86 & 0.10 & -7.95 & 0.00 \\
CDS 10Y & 0.39 & 0.14 & -2.36 & 0.00 \\
Constant & 4.59 & & & \\
\hline
\end{tabular}

The VECM results on table 7 shows that the cointegration equation does not appear as significant in the 10 year CDS equation, while it appears significant in the domestic long term equation and the US real rate. Thus, the adjustment coefficients of the model indicate that the domestic long term real rate responds more quickly than the others variables after a change in the system, while the risk premium does not adjust, which is equivalent to say that the risk premium, measured by the 10 year CDS spread is weakly exogenous, and also the US real rate at the $5 \%$ level.

The LM test indicate the the residuals do not display autocorrelation, with a p-value of 0.17 in the first lag. The model also passes the stability test, shown on figure 3 .

Finally, figure 4 shows the predicted cointegration equation over time and compares it to the residuals obtained from the Engle and Granger methodology, based on the equation presented on table 5. Both show a similar evolution over time, very close to each other. Apart from the period during the global financial crisis of 2008, the cointegration equation seems to be stationary. As mentioned earlier, the Philips-Perron test rejects the null of a unit root, while the DF-GLS test fail to reject the null of a unit root.

\section{DISCUSSION}

Having found a model that describes well the evolution of long term real interest rates in Brazil, we can gauge the contribution of each explanatory variable over time. This exercise was done with the specification on the first column on table 2.

Figure 5 shows the evolution of the long real rate and the contributions over time of risk premium and US real rate. This rate displays a downward trend over time. With the exception of the period of the great financial crisis of 2008, overall Brazilian real rates followed this declining trend. From November 2011 to May 2013, US real rates exerted a negative contribution for domestic long term real rate, influenced by the second and third rounds of US Quatitative Easing (QE), which ended with the "taper tautrum" episode, when the chairman of the Federal Reserve signaled that the institution planned to begin monetary policy normalization. This event and related consequences for emerging markets are described in Eichengreen and Gupta (2013) and Aizenman et al. (2014). 
BBR

14,6

632

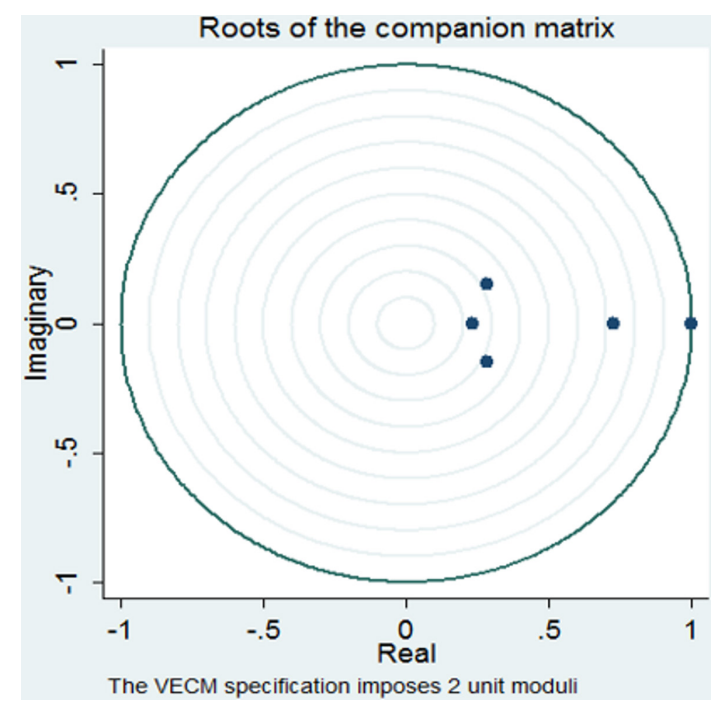

Figure 3. Stability of the estimated VECM

Table 7. Vector Error Correction model

\begin{tabular}{lccc}
\hline VARIABLES & $(1)$ & $(2)$ & $(3)$ \\
& $\Delta$ Real Rate & $\Delta$ US Real Rate & $\Delta$ CDS 10Y \\
\hline Cointegration Equation (-1) & $-0.151^{* * *}$ & $0.0671^{*}$ & -0.0288 \\
& $(0.0497)$ & $(0.0382)$ & $(0.0562)$ \\
$\Delta$ Real Rate(-1) & $0.189^{*}$ & -0.0674 & -0.0585 \\
& $(0.107)$ & $(0.0820)$ & $(0.121)$ \\
$\Delta$ US Real Rate (-1) & 0.158 & $0.240^{* *}$ & 0.0388 \\
& $(0.126)$ & $(0.0968)$ & $(0.142)$ \\
$\Delta$ CDS 10Y (-1) & $0.166^{*}$ & 0.0667 & $0.302^{* * *}$ \\
Constant & $(0.101)$ & $(0.0777)$ & $(0.114)$ \\
Observations & -0.00789 & -0.0128 & 0.0116 \\
\hline
\end{tabular}

Standard errors in parentheses

*** $\mathrm{p}<0.01,{ }^{* *} \mathrm{p}<0.05,{ }^{*} \mathrm{p}<0.1$

Findings of these papers indicate that large and liquid emerging markets, along with those that suffered the largest real exchange rate appreciation and wider current account deficits were more affected by the tapering news, which was the case of Brazil (Eichengreen and Gupta, 2013, p.4). In addition to higher spreads, as emphasized in the aforementioned papers, the transmission for Brazilian real rates was also due to higher US real rates following tapering news. The same dynamics happened at the time of the great financial crisis of 2008. The difference is mainly in the scale. At the height of the financial crisis, in October 2008, the risk premium literally skyrocketed. US real rates also surged, and in comparison to the tapering episode, the contribution of US real rates to domestic real long term rates was much higher in 2008.

Overall Brazilian real rates display a high correlation with 10 year US real rates. For the whole sample, the correlation is 0.81 . Despite the turnaround after the tapering news, since August 2013 the contribution of US real rates to Brazil's has remained fairly stable, with 


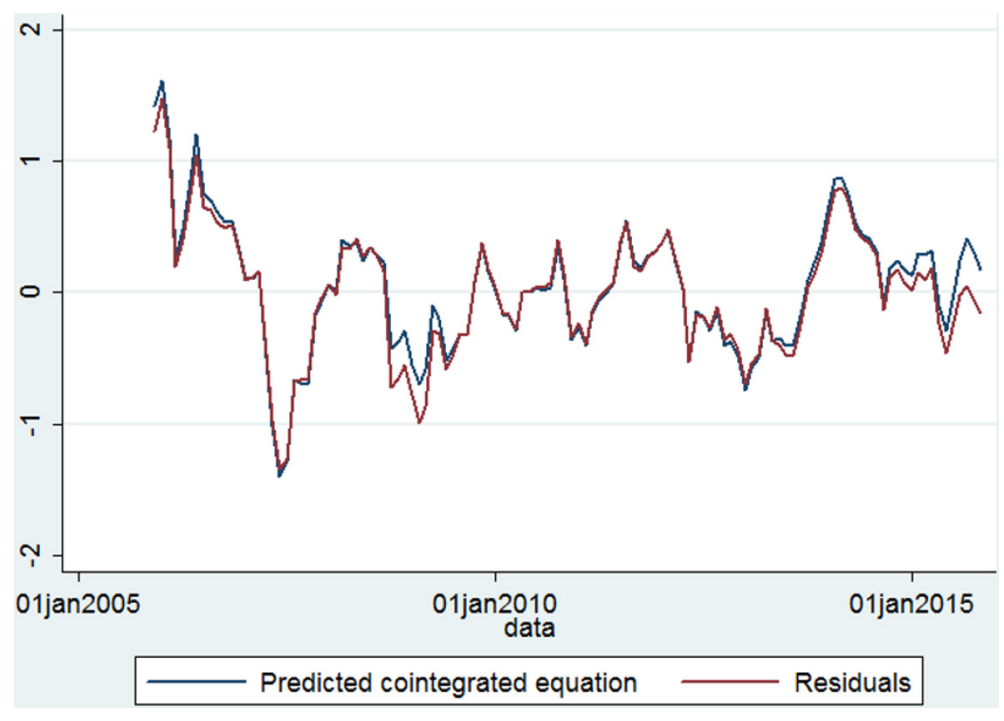

Figure 4. Comparision of the predicted cointegration equations of the Engle and Granger and Johansen methodology

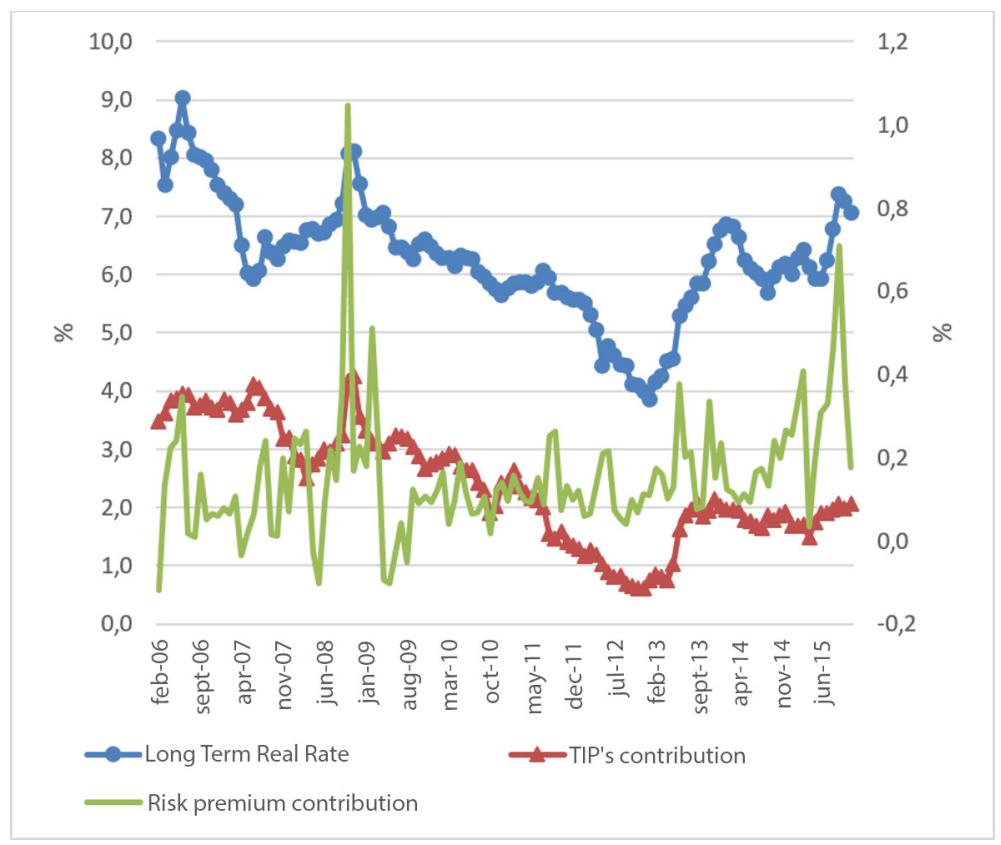

Figure 5. Contributions to the long term real rate

the movements in Brazilian real long term rates been driven basically by the risk premium, which rose significantly in the more recent period.

One interest thing is that, although the Central Bank of Brazil began to raise rates in April 2013, the model does not indicate that policy rate is a significant driver of long term real rates, implying that the increase in long real rates in Brazil over the first half of 2013 was mostly due to US real rates. Exercises indicate that policy real rates are not significant once we account for a contemporaneous effect of US real rates and risk premium to long term domestic real rates. Ignoring this contemporaneous effect, in a multivariate framework, a Granger causality based on a VAR(4) including real Selic rates and long term real rates indicates that the former Granger cause the latter, with associated p-value of 0.02 , while we fail to reject the hypothesis that long term real rates does not Granger cause Selic real rates, with associated p-value of 0.46 . 
BBR

14,6

634

One might argue that the high levels of interest rates in Brazil could be a cause of the high risk premium. But the data clearly reject this argument. Based on a bivariate VAR between real rates and CDS spreads over the sample period, Granger causality tests indicate that risk premium Granger cause domestic real rates, while the opposite does not hold, indicating that risk premium precedes real rates over time. Results are presented on table 8, based on a VAR(2) with 118 observations.

Table 8. Granger causality tests between long term real rates and risk premium

\begin{tabular}{lllc}
\hline Equation & Excluded & Qui $^{2}$ & Prob> $^{2}$ ui $^{2}$ \\
Real Rate & CDS 10Y & 5.97 & 0.05 \\
CDS 10Y & Real Rate & 0.78 & 0.67 \\
\hline
\end{tabular}

\section{CONCLUSION}

This paper tried to model long term real rates in Brazil. Previous studies that sought to explain or model real interest rates in Brazil used short term real rates (policy or swap rates), sometimes as a measure of long term rates. Figure 1 and descritive statistics indicated that policy rates and other short term real rates are much more volatile as compared to long term rates, based on yield of bond with maturities of more than 30 years. The findings of previous studies may by contaminated by that higher volatility. This paper is closer in content to Bonfim (2001), who tried to extract information about neutral real rates for the US from inflation linked bonds.

The main finding of this research is that long term real rates in Brazil are mainly driven by 10 year US real rates and 10 year risk premium, as measured by CDS spreads. Proxies for technical factors affecting the market for inflation linked bonds were not significant. Variables traditionally employed in previous studies about the sources and determinants of Brazilian high interest rates, as debt levels and credit market indicators, were found not to significantly affect long term real rates.

Long term real rates were on a downward trend until the "Taper Tantrum" in May 2013, which led to a reversal in the behavior of US real rates. From November 2011 until May 2013, US real rates exerted a negative contribution to domestic real long term rates, related to -unconventional monetary policy measures. Since mid-2013, the contribution of US real rates for domestic long term rates has remained flat. The increase in real rates has been mainly a function of spikes in the risk premium.

Based on the cointegration relationships in section 4, absent influences from foreign real rates and the risk premium, estimates of the equilibrium (natural or neutral) long term real rates in Brazil lie between 4.4 and $4.6 \%$ over the sample period. These estimates should be perceived as a floor for real rates in Brazil, considering the methodology employed in this paper, based on long term relationships between domestic long term market rates, risk premiums and foreign long term real rates.

Finally, it was not found a relevant role for monetary policy on long term real rates, once the contemporaneous effects of the risk premium and foreign rates on domestic rates are taken into account. This finding echoes those from the classical economists, who believed that the long term real rate was determined by economic fundamentals and the interest structure is anchored by the long term real rate, rather than the expectation hypothesis (Humphrey 1983; Thornton, 2012), which might warrant further research.

\section{REFERENCES}

Aizenman, J, B Mahir, and M Hutchison (2014), “The Transmission of Federal Reserve Tapering News to Emerging Financial Markets”, NBER Working Paper 19980. 
ARIDA, P., BACHA, E., e LARA-RESENDE, A. Credit, Interest, and Jurisdictional Uncertainty: Conjectures on the Case of Brazil. IEPE/CdG,1-25, 2004

Bacha, Edmar (2010), “ALÉM DA TRÍADE: HÁ COMO REDUZIR OS JUROS?” Available at http://iepecdg. com.br/uploads/texto/101020EdmarCOMO REDUZIR OS JUROS.pdf. Access on February 20, 2016.

Bomfim, Antulio, 2001, "Measuring Equilibrium Real Interest Rates: What Can We Learn from Yields on Indexed Bonds?" Board of Governors of the Federal Reserve System FEDS 2001-53.

Eichengreen, B and Gupta, P (2013), “Tapering Talk: The Impact of Expectations of Reduced Federal Reserve Security Purchases on Emerging Markets", World Bank Working Paper.

Goldfajn, I., and A. Bicalho, 2011, "A Longa Travessia para a Normalidade: Os Juros Reais no Brasil," in Novos Dilemas da Política Econômica - Ensaios em Homenagem a Dionisio Dias Carneiro, edited by E. L. Bacha e M. B. de Bolle. Rio de Janeiro: Grupo Editorial Nacional.

Gonçalves, F. M., M. Holland, and A. D. Spacov, 2007, "Can Jurisdictional Uncertainty and Capital Controls Explain the High Level of Real Interest Rates in Brazil? Evidence from Panel Data," Revista Brasileira de Economia, Vol. 61, n. 1, p.p. 49-75.

Humphrey, Thomas M. 1983, "Can the Central Bank Peg Real Interest Rates? A Survey of Classical and Neoclassical Opinion.” Federal Reserve Bank of Richmond Economic Review, 12-21.

Jaeger, Markus (2012), "Government Debt \& Real Interest Rates in Brazil - Reviving the 'Fiscal' Hypothesis." Available at http://iepecdg.com.br/uploads/texto/CDG_2012.pdf Access on February 20, 2016.

Muinhos, Marcelo Kfoury and Marcio Nankane, 2006, "Comparing Equilibrium Real Interest Rates: Different Approaches to Measure Brazilian Rates," Central Bank of Brazil Working Paper No. 101.

Magud, Nicolas E., and Evridiki Tsounta, 2012, "To Cut or Not to Cut? That is the (Central Bank's) QuestionIn Search of the Neutral Interest Rate in Latin America," IMF Working Paper 12/243.

Neto, Paulo Chananeco and Marcelo Savino Portugal, 2009, "The Natural Rate of Interest in Brazil Between 1995 and 2005," Revista Brasileira de Economia Vol. 63 No. 2, pp. 103-118.

Perrelli, Roberto, and Shaun Roache, 2014, “Time-Varying Neutral Interest Rate----The Case of Brazil,” IMF Working Paper 14/84 (Washington: International Monetary Fund).

Segura-Ubiergo, Alex. The puzzle of Brazil's high interest rates, IMF Working Paper 62, 2012

TELES, V. K.; RIBEIRO, A. Taxa Natural de Juros no Brasil. Economia (Brasília), v. 14, p. 733-750, 2013.

Thornton, Daniel L. (2012) "Greenspan's Conundrum and the Fed's Ability to Affect Long-Term Yields," Federal Reserve Bank of St. Louis. Working Paper 2012-036A. 